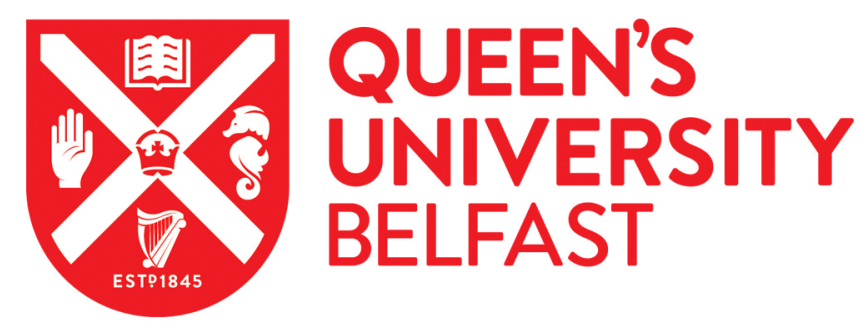

\title{
Geographic distribution of the Ciclovia and Recreovia Programs by neighborhood SES in Bogotá: How unequal is the geographic access assessed via distance-based measures?
}

Parra, D. C., Adlakha, D., Pinzon, J. D., Van Zandt, A., Brownson, R. C., \& Gomez, L. F. (2020). Geographic distribution of the Ciclovia and Recreovia Programs by neighborhood SES in Bogotá: How unequal is the geographic access assessed via distance-based measures? How Unequal is the Geographic Access Assessed Via Distance-based Measures? Journal of Urban Health, 98(1), 101-110. https://doi.org/10.1007/s11524-02000496-w, https://doi.org/10.1007/s11524-020-00496-w

Published in:

Journal of Urban Health

Document Version:

Peer reviewed version

Queen's University Belfast - Research Portal:

Link to publication record in Queen's University Belfast Research Portal

Publisher rights

Copyright 2020 Springer. This work is made available online in accordance with the publisher's policies. Please refer to any applicable terms of use of the publisher.

\section{General rights}

Copyright for the publications made accessible via the Queen's University Belfast Research Portal is retained by the author(s) and / or other copyright owners and it is a condition of accessing these publications that users recognise and abide by the legal requirements associated with these rights.

\section{Take down policy}

The Research Portal is Queen's institutional repository that provides access to Queen's research output. Every effort has been made to ensure that content in the Research Portal does not infringe any person's rights, or applicable UK laws. If you discover content in the Research Portal that you believe breaches copyright or violates any law, please contact openaccess@qub.ac.uk. 
1 Geographic distribution of the Ciclovia and Recreovia Programs by neighborhood SES in

2 Bogotá: How unequal is the geographic access assessed via distance-based measures?

\section{Abstract}

4 Ciclovia, also known as Open Streets initiatives in other countries, are city streets that are closed

5 to motorized traffic and opened during certain times to residents for engaging in physical activity

6 (PA). These initiatives are viewed by policy makers and health and community advocates as

7 being beneficial to social, environmental, and community health. This study explores the

8 geographic distribution of Ciclovia and Recreovia and the differences in geographic access

9 assessed via distance-based measures, based on the socioeconomic status (SES) of the area.

10 Results from this study show that the median distance to the Ciclovia according to SES ranges

11 from 2,930 meters for SES 1 (most disadvantaged) to 482 meters for SES 6 (wealthiest). The

12 median distance to the Recreovia sites ranges from 5,173 meters for SES 1 to 3,869 meters for

13 SES 6. This study found revealing urban inequities in the distribution of Ciclovia whereas there

14 was less inequalities within the Recreovia sites. This study shows that urban interventions are 15 needed to promote recreational activity and reduce health disparities in under resourced, low SES 16 areas.

\section{Introduction}

18 Community-based programs are feasible, cost beneficial and effective methods to easily integrate

19 the practice of physical activity (PA) into daily life while increasing physical, social and mental

20 health benefits. ${ }^{1-4}$ A community-based program called Ciclovia, which reserves car free streets to

21 allow exclusive access for pedestrians, cyclists, skaters, and others forms of active recreation,

22 was developed in Bogotá Colombia in 1974..$^{5}$ The current coverage involves a distance of 127.69

23 kilometers (79.3 Miles) of major avenues, these streets are closed every Sunday and holidays

24 from 7 AM to $2 \mathrm{PM}^{6}$ This program has a 44-year history and approximately 600,000 to

25 1,400,000 users participate every Sunday and holiday. ${ }^{6}$ Ciclovia programs also known as "open

26 streets" in the United States, are expanding rapidly worldwide and are found in at least 20

27 countries in North, Central, and South America. ${ }^{7-16}$ 
30 The Ciclovia initiative emerged in Bogotá in December 1974 within a context of explosive urban 31 growth which started to take place in the 1950's in the majority of large Latin American cities. ${ }^{17}$

32 Due to lack of a long-term urban planning strategy, more than $50 \%$ of the neighborhoods in

33 Bogotá have low availability of green areas and public recreational spaces. ${ }^{18}$ According to the

34 Mayor's Office of Bogotá, the average green area per inhabitant is $6.6 \mathrm{~m}^{2}$, ranging from $1.9 \mathrm{~m}^{2}$ in

35 one of the lowest income neighborhoods in the city to $14.8 \mathrm{~m}^{2}$ in a middle-high income

36 neighborhood district. ${ }^{19}$ Consequently, the Ciclovia Program in Bogotá could serve as a response

37 to the deficits in the availability of public parks and other recreational spaces. ${ }^{17,19}$ From 1974 to

38 1994, a total of $21 \mathrm{~km}$ of Ciclovia were built in middle-to-high socioeconomic neighborhoods. ${ }^{20}$

39 Further history on the Ciclovia and Recreovia programs can be found elsewhere. ${ }^{5}$ One of the reasons why the program was predominately in high-to-middle income areas was due to the availability of high quality and paved roads, thus making it easier to implement the program. By

42 the year 2000, the Ciclovia Program expanded to $120 \mathrm{~km}$, covering middle-to-low SES neighborhoods and reducing the urban inequity in its geographic distribution. ${ }^{21}$

Ciclovia's sister program known as "Recreovia" began on April 16, 1995 as a community based PA program offering aerobic and dance classes in specific sites throughout the city, in order to add value to the Ciclovía users and improve their quality of life. The first physical activity point was the centrally located National Park (Pictured on Figure 5), which offers a large space and amenities for the implementation of the activities. The physical activity classes offered by the Recreovia program are informed by current scientific guidelines and delivered by highly qualified teachers.

51 Recreovia takes place in 44 sites throughout the city, located along the Ciclovia, where free of 52 charge aerobic and dance classes continued to be offered to the population. ${ }^{22,23}$ Twenty-eight of 53 these points offer classes during the same times that the Ciclovia takes place. The remaining points

54 offer classes during selected one or two days of the week. Sarmiento et al. found this program to 55 be especially effective for women who are less likely to meet the PA recommendations during 56 their leisure time. ${ }^{22}$ This study found that the percentage of women was higher in parks with 57 Recreovía, compared to parks without Recreovía. The prevalence of physical activity during 58 leisure time among women in Bogota is only 23.8\%, compared to 28.2 among men. A recent paper 59 evaluating the Recreovia program found that multi-sectoral strategies to promote active recreation 
and PA in public spaces such as Recreovia are crucial to building a "culture of health". According to their findings, the Recreovia program has undergone adaptation processes to address the challenges that threatened their continuation and growth, in this sense being flexible and adaptable has been crucial to its survival. ${ }^{24}$

A survey of 67 Ciclovías in Latin America characterized their overall distribution among the studied countries. The study showed that $53.7 \%$ of the Ciclovias included low-income areas, $89.3 \%$ connected different income areas, and $61.2 \%$ included routes in areas with a predominance of minority populations (ethnic groups, internally displaced populations, other minorities). ${ }^{25}$ However, the particular distribution of Ciclovia in Bogota does not correspond to this type of distribution based on prior research and the results from the current study.

Physical inactivity is strongly associated with chronic non-communicable diseases, which contribute to 3.2 million deaths each year globally and cause 69.3 million deaths and disabilityadjusted life years (DALYs). ${ }^{26}$ Given that physical inactivity is a leading global risk factor for death, widespread promotion and delivery of PA programs should be a public health priority. Guthold et al. estimate that more than a quarter of adults in the world do not meet PA recommendations for health, ${ }^{27}$ which suggests that community-based PA programs such as Ciclovia and Recreovia can play an important role in PA promotion. ${ }^{22}$ Furthermore, Colombian women from low SES populations are more at risk for physical inactivity, which supports the relevance and need for this study. ${ }^{28}$

The purpose of this study is to use distanced based indicators in order to describe the geographic distribution of the Ciclovia and Recreovia programs according to the socioeconomic status of 4 Bogotá's neighborhoods. Ciclovia is currently the largest PA program in the world, ${ }^{23}$ but inequities in their access remain. A study carried out using data from 2009 found that the Ciclorutas (bicycle lanes) and the Ciclovía recreational program do not offer equal geographic access for all SES, especially for the lower SES. This is despite the fact that most of the users of the programs are from low and middle income SES. They concluded at the time that marginal route extensions, that is the expansion of Ciclovia, can improve equity in geographic access. ${ }^{29}$ The program has been shown to increase social capital, ${ }^{30} \mathrm{PA}$ levels, ${ }^{31-32}$ bicycle use during the 
91 week for transportation, ${ }^{33,34}$ and demonstrated to be a cost beneficial program. ${ }^{35}$ However it is

92 also essential to explore distribution of the Ciclovia and understand the inequities of geographic

93 proximity to these recreational activities.

\section{Methods}

96 A spatial epidemiological study was undertaken using secondary data obtained through

97 Geographic Information Systems. This data was provided by the Cadastre Office of Bogotá

98 which collected this information in $2015 .{ }^{36}$

99

100

Blocks were defined as the urban space delimited by streets. For the purpose of this study, only

101 residential blocks were included in the analysis. The total number of blocks in Bogota is 45,053 and, in this analysis, we used all 33,405 residential and mixed-use blocks, representing $74 \%$ of the city. Residential blocks are usually between 100 and 150 meters in length and are used exclusively for residential purposes according to the urban planning department. The block includes two sidewalks facing each other. ${ }^{37}$ The 2015 Ciclovia distribution and the Recreovia points were obtained from the Institute for Sports and Recreation. ${ }^{38,39}$

Blocks were classified in six categories of socio-economic status (SES), from SES 1 (lowest) to SES 6 (highest). These categories were pre-established by Cadastre for determining the price of public utilities and taxes which uses physical attributes of the surrounding environments (i.e., road and pedestrian infrastructure) and housing (i.e., construction types and materials). ${ }^{40}$ This socio-economic stratification system was implemented in Colombia in the 1980's in order to

113 classify areas of similar economic characteristics using a scale from 1 to 6 , with 1 being the most disadvantaged and 6 the wealthiest. The system became a law in 1994, providing a framework for granting subsidies in public utilities to the poorest residents. $68 \%$ of Bogotá's residents live in strata 2 and $3 .{ }^{41}$ The poorest population is concentrated in the periphery with mostly hilly terrain in the south and south-west of city in informal dwellings. ${ }^{19}$ The social stratification system was originally intended to benefit those with lower incomes, however it has become a system that divides by creating stigma and discrimination among the citizens. ${ }^{42}$ 
123 The shortest distance from the centroid of each of the residential blocks to the closest access

124 point to the Ciclovia and Recreovia site was calculated using Network analyst (ArcGIS 10.3). An

125 access point was defined as any point along the linear layer for the Ciclovia. We used the "Make

126 Closest Facility Layer" tool of the Network Analyst extension to calculate the distance between

127 the centroid of a block to the closest point of geographic access to a Ciclovia and to a Recreovia

128 site. This procedure was made in Cartesian coordinate space $(\mathrm{X}, \mathrm{Y})$. For this we calculated the

129 Manhattan distance, which considers road network to calculate the shortest distance between the

130 origin and destination points. ${ }^{47} \mathrm{We}$ used the street network grid data of Bogotá from 2016,

131 available from IDECA (Center for Spatial Data Infrastructure for Bogotá), ${ }^{41}$ and the Ciclovia's

132 official data from the Institute of Sports and Recreation. ${ }^{42,43}$ The result of the Make Closest

133 Facility analysis produced a network of lines that connect each block's centroid with the closest

134 point of the Ciclovia based upon the shortest distance following the street network grit, using

135 meters as the distance unit. ${ }^{40}$ We conducted a Kruskal-Wallis equality of populations rank test to 136 determine statistically significant differences in the distances between the different categories of 137 SES.

Tables 1 and 2 show the results for the Ciclovia and Recreovia analysis respectively. The 39.9\%

142 SES 6. The overall median distance from block centroids to the closest Ciclovia was 1,848

143 meters (see Table 1). The median distance to the Ciclovia according to SES ranges from 2,938

144 meters for SES 1 (most disadvantaged), 2,349 meters for SES 2, 1,306 meters for SES 3, 784

145 meters for SES 4, 716 meters for SES 5, and 482 meters for SES 6 (wealthiest) (Table 1). These

146 variations were statistically significant $(\mathrm{p}<0.001)$. This is over a six-fold difference in distance to

147 Ciclovia from the lowest to highest SES group. Of the total blocks, $71 \%$ were over $1000 \mathrm{~m}$ from

148 the closest geographic access point to the Ciclovia corridor. For SES 1, 96.4\% of the blocks were greater than $1000 \mathrm{~m}$. For SES 6, only $12.5 \%$ of the blocks were over $1000 \mathrm{~m}$.

150

151 Table 2 shows the overall median distance from block centroids to the closest Recreovia point 152 which was 2,125 meters. The median distance to the Recreovia sites according to SES ranges 
153 from 5,173 meters for SES 1 (most disadvantaged), 2,117 meters for SES 2, 1632 meters for SES

$1543,1,800$ meters for SES 4, 3,041 meters for SES 5, and 3,869 meters for SES 6 (wealthiest).

155 These differences were statistically significant $(\mathrm{p}<0.001)$.

157 Figure 1, shows a graphic representation of the distribution of Ciclovia and Recreovia by 158 neighborhood SES. The map shows a greater distribution of Ciclovia in blocks of higher SES, 159 those in dark blue and blue, compared to the areas in dark red and red. Figure 1, also shows a 160 somewhat more equal distribution of Recreovia points by SES, compared to Ciclovia. Similarly, 161 as argued before, we can observe in the map that the distribution of Recreovia sites and Ciclovia 162 are not reaching neighborhoods of low SES where there is also a deficit of the distribution of 163 public parks.

165 Fig. 1 Distribution of Recreovia Sites and Ciclovia in Bogotá by neighborhood SES

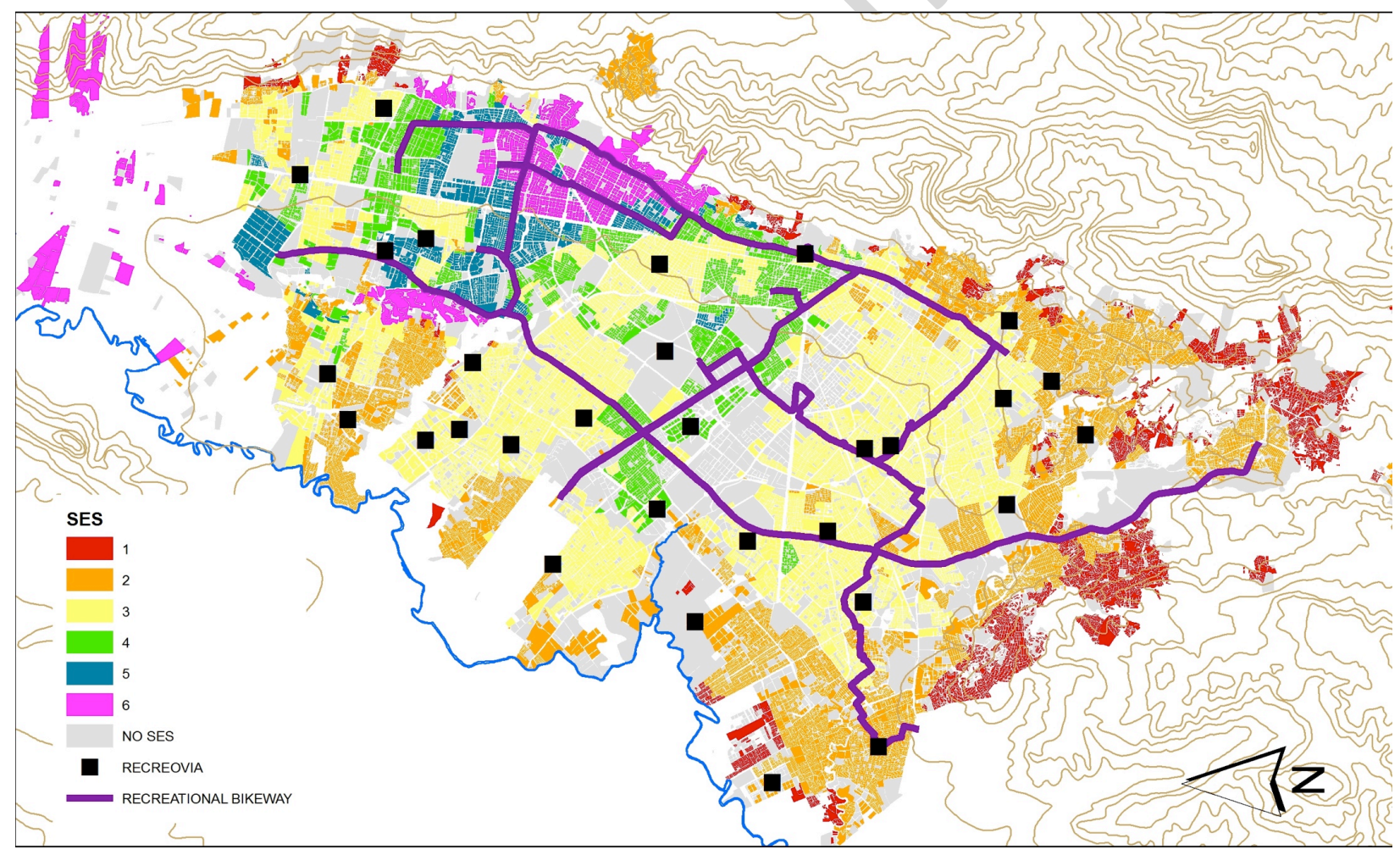

167 Figures 2-4, include pictures of the Ciclovia program in Bogota, taken during a typical Sunday in

168 2018, in different socio-economic strata neighborhoods in Bogota. Figure 5 includes a picture

169 from the Recreovia program taken during a regular Sunday at the National Park, the oldest

170 Recreovia point in the city. 
171 Fig. 2 Ciclovia in an avenue surrounded by SES 4 neighborhoods

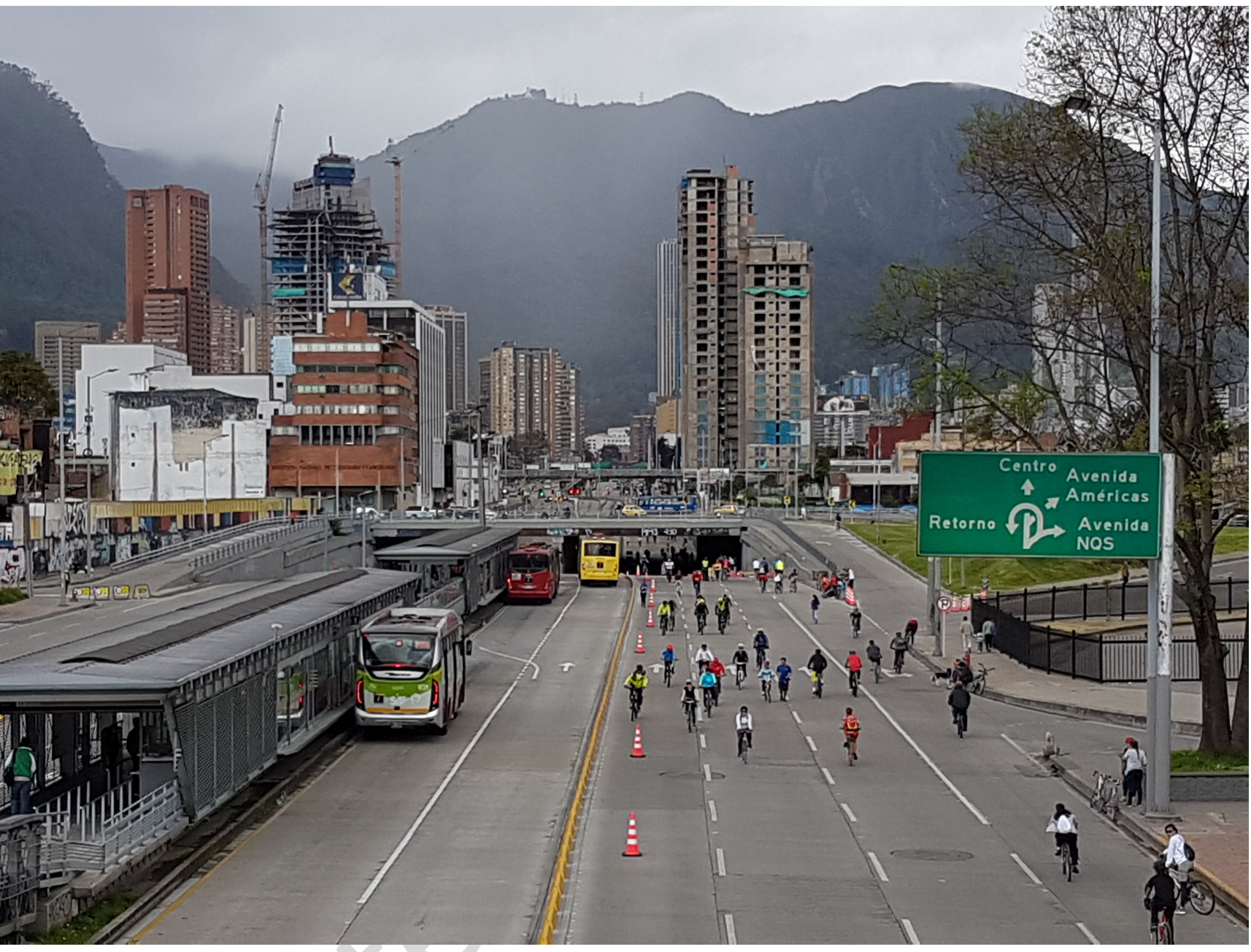


185 Fig. 3 Ciclovia in an avenue surrounded by SES 3 neighborhoods

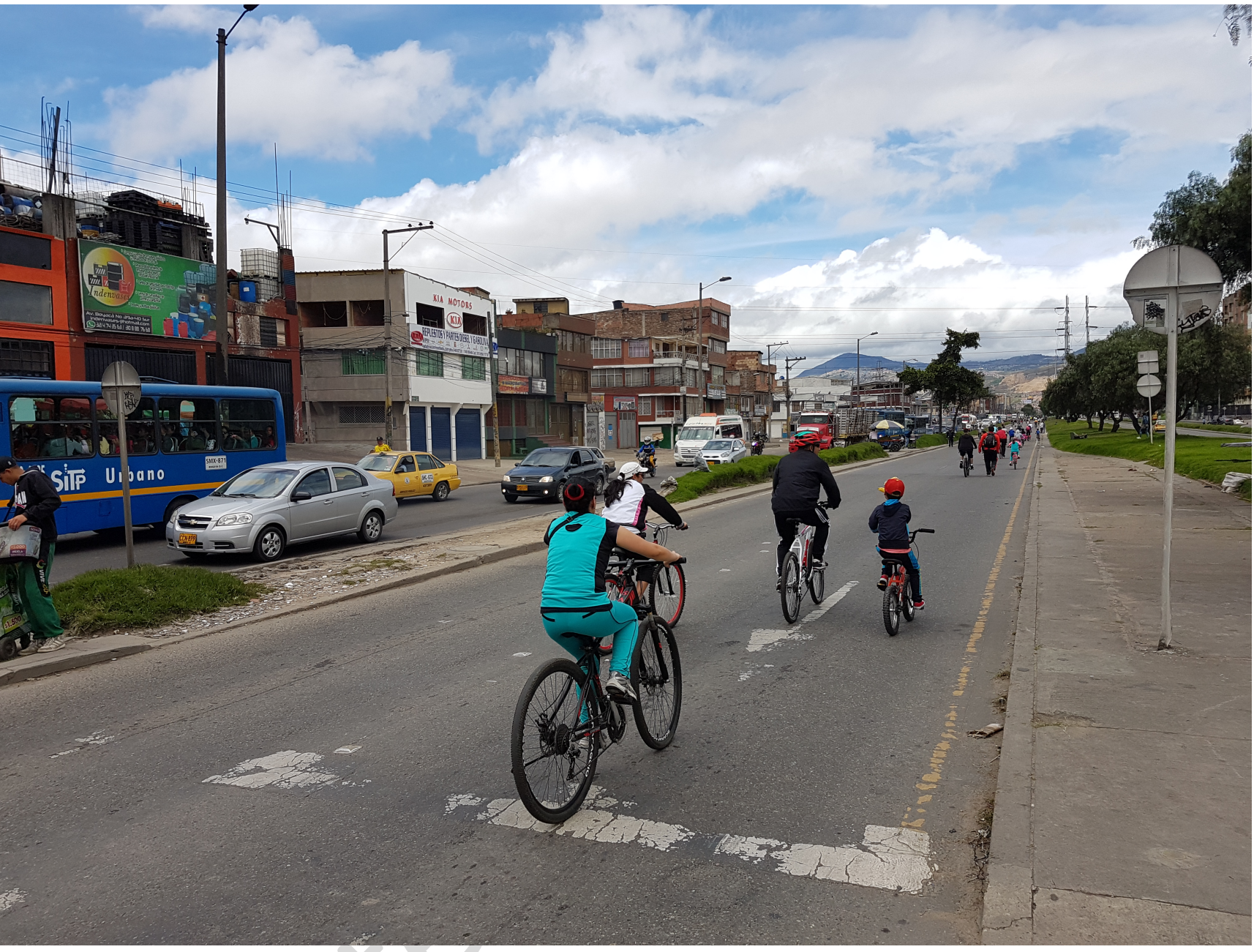

186

187

188

189

190

191

192

193

194

195

196

197

198 
199 Fig. 4 Ciclovia in an SES 2 neighborhood

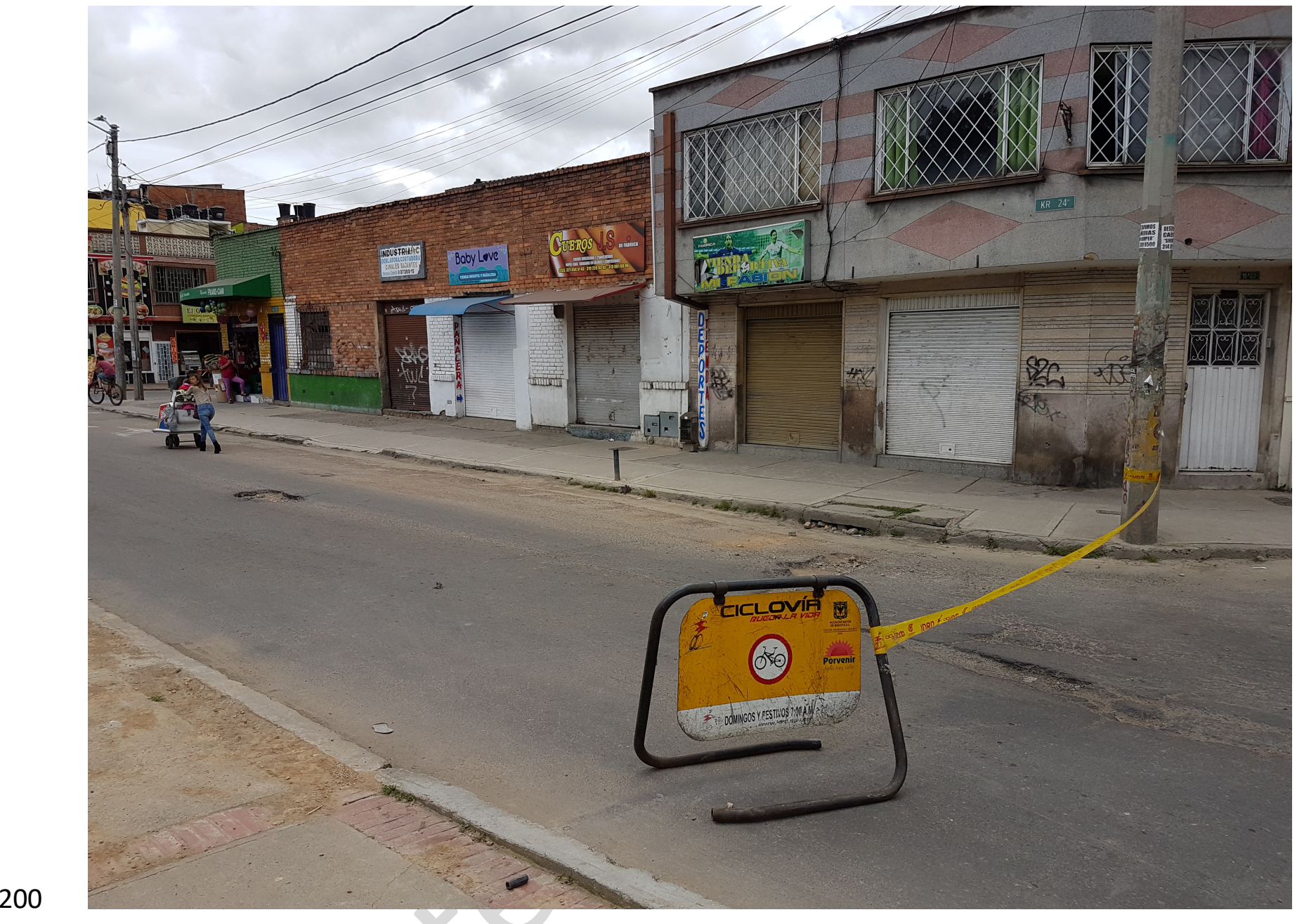

201

202

203

204

205

206

207

208

209

210

211

212 
Fig. 5 Recreovia Site from SES 4

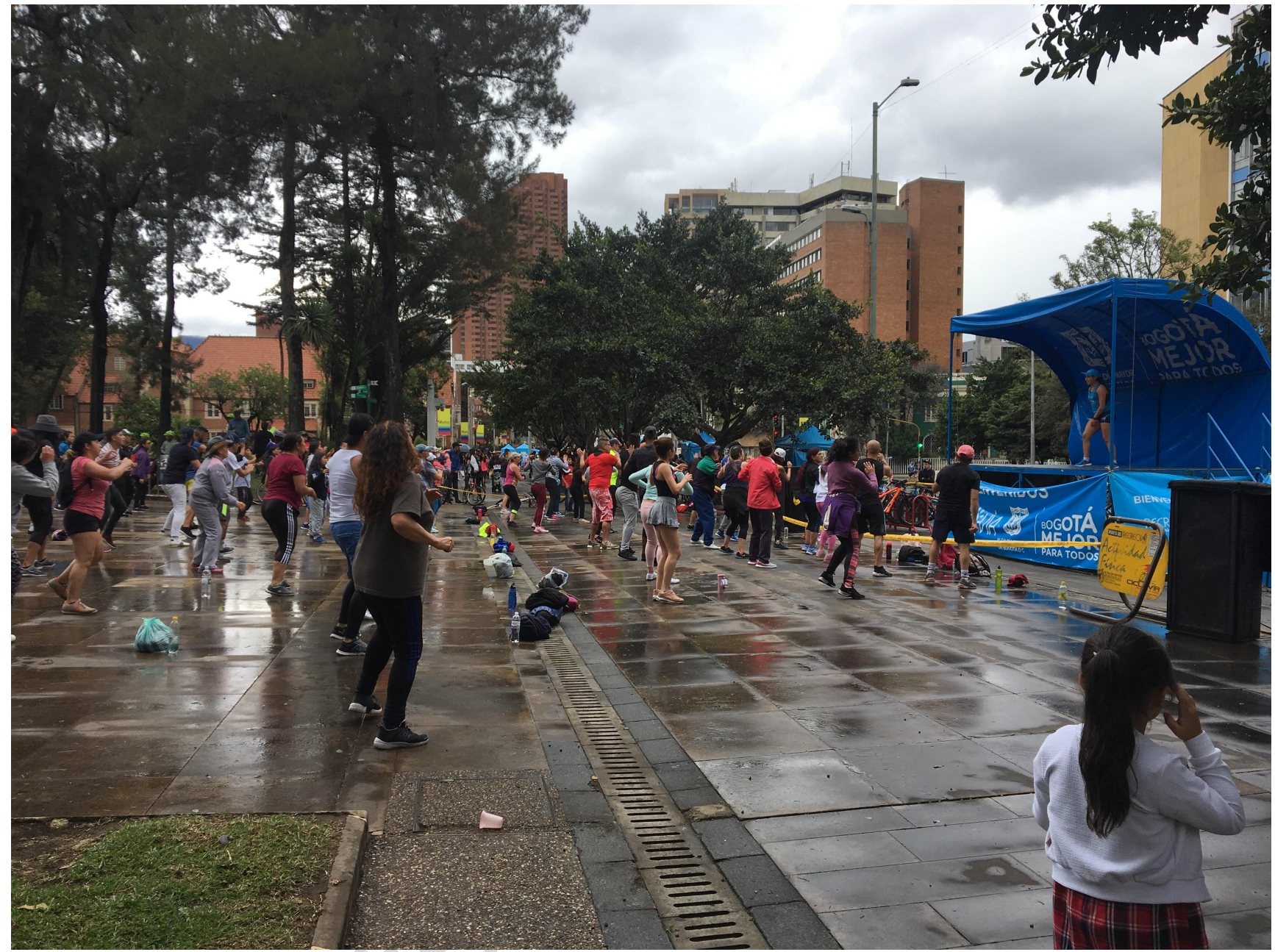

217 This study suggests that there are inequalities in the geographic distribution of Ciclovia in terms

218 of distance-based measures, while the disparity appears to be lower for Recreovia sites. This

219 study extends the current state of research on Ciclovia and Recreovia programs in Bogotá by

220 examining the geographic distribution and differences in proximity according to the

221 socioeconomic status of the neighborhoods. ${ }^{40}$ It is important to acknowledge that the distribution

222 of geographic access to Ciclovia by socioeconomic status is likely a context-specific matter, and

223 the current analysis for Bogota cannot be used as evidence to inform action in other settings.

224 However, it can be used as a process to generate equivalent indicators in cities with Ciclovias

225 across the globe. 
226 This study found that SES groups 1, 2 and 3 had a farther distance to travel to the Ciclovia than

227 did SES 4, 5 and 6, with SES group 1 having a six-fold difference compared to the highest SES.

228 These results confirm our hypothesis of the unequal geographic accessibility of the Ciclovia for

229 low SES neighborhoods in Bogotá Colombia assesses via distance-based measures, which was

230 also confirmed when exploring access to Bogotá's public network of bicycle paths. ${ }^{40}$

231

232 Furthermore, Figure 1 reveals that Ciclovia is scarcely found in SES 1 neighborhoods and there

233 are fewer Ciclovias in SES 2 and 3 neighborhoods. Conversely, neighborhoods in SES 4 have to

234 travel on average 1,023 meters, and SES 5 and 6 have less than $1,000 \mathrm{~m}$ to travel to

235 geographically access the closest Ciclovia. Our results support the findings by Teunissen et al.,

236 in regards to the unequal geographic access of the program Ciclovía for the lower SES groups

237 using data from $2009 .^{29}$

238

239 Though still unequally distributed, the Recreovia program is more geographically accessible to

240 lower SES neighborhoods (Figure 1). As demonstrated by Sarmiento et al. ${ }^{24}$ the Recreovia

241 program has great potential for increasing PA levels particularly among women, who are at

242 higher risk of being sedentary. The fact that geographic access to Recreovia is better for low-

243 income neighborhoods compared to the Ciclovia might be partially explained by the role of

244 disparities in already existing infrastructure (e.g. street quality, street design, street lighting)

245 which contributes to differential access to Ciclovia routes. For instance, Open Streets initiatives

246 use existing infrastructure, impacting where the route will be located, while Recreovia uses parks

247 and other open spaces, also existing, but more adaptable to the current conditions of the

248 neighborhood income.

250 Figure 1 also shows that along with a lower number of Ciclovia and Recreovia sites, areas of low

251 SES also have a deficit of public parks, further highlighting the inequity of recreational

252 opportunities for the population of Bogota who are under resourced. The percentage of the

253 population of Bogota from SES 1 (10.4\%) and SES 2 (41.3\%) was 51.7\% as of 2014.

255 Unequal distribution is a problem because Ciclovia and Recreovia are public health initiatives

256 that encourage leisure time PA, and lower SES groups have been associated with higher levels of 
257 physical inactivity. ${ }^{48}$ According to the National Nutrition Survey of Colombia conducted in

258 2015, the prevalence of having met leisure time PA among adults was positively associated with

259 income. ${ }^{26}$ Likewise a research study in Brazil found an association between low socioeconomic

260 status and a lack of leisure time PA. ${ }^{49}$ Despite this inequity, the mission and goal of the

261 Recreovia and the Ciclovia programs is to reduce the unequal access to recreational activities and

262 to benefit the community as a whole. ${ }^{50,51}$

263

264 Unfortunately, other public health programs offered in Bogotá, such as the Cicloruta, are also not 265 in close proximity to lower SES neighborhoods. ${ }^{40}$ However, geographic access includes more

266 than proximity as some studies have found that proximity alone does not guarantee access or use

267 of a particular resource, such as a public bicycle share program ${ }^{52}$ and trail network

268 accessibility. ${ }^{53}$

269

270 Our study uses simple statistics (mean/median/range) to determine differences in the proximity

271 to a large scale, urban community program for health promotion, while controlling for the slope

272 of the terrain. Our study design of measuring and comparing the distance from the centroid of

273 each block within all city neighborhoods classified by SES, to a geographic access point of a

274 Ciclovia or Recreovia site can be easily adopted and replicated by other cities around the world.

275 This type of data could be useful for public health policy, research, and programs for promoting

276 health and reducing inequities and disparities, while at the same time creating a repository of

277 comparable data. At the local level, this can have immense impact, by pointing out priority areas

278 of expansion and investment, towards a more equitable Ciclovia/Recreovia and community-

279 based public health system in cities.

281 This study has several limitations that should be noted. Primarily, Ciclovia and Recreovia

282 initiatives were not designed as an intervention study and there are limitations associated with

283 this uncontrolled evaluation. Residential block centroids were used to obtain the distance

284 between the center of the block and the closest geographic access to the Ciclovia or Recreovia

285 site, rather than measuring individual addresses, which would have provided more accurate

286 distance information. This study did not consider other forms of geographic access, such as road

287 connectivity, public transit availability, and quality of the roads. Furthermore, economic access 
288 should also be considered when analyzing and interpreting levels of social equity and disparity.

289 For example, it should be taken into account if the individuals can afford the time or resources

290 for transportation to gain access to these programs. Therefore, access should be assessed in a

291 variety of forms in order to address health disparities and promote health equity. This study

292 measured access specifically related to geographic access using only distance-based measures.

293 However, access as a broader construct includes aspects such as cultural/acceptability access,

294 and availability of destinations (density \& count-based measures) among others.

295 Despite these limitations, results of this study highlight the need to expand and refine the

296 measurement of PA to include the possibility of identifying how environmental factors outside

297 the neighborhood may also have an influence on patterns of PA.

299 In Bogotá, inequalities in the quality and availability of recreational resources have been

300 previously acknowledged. ${ }^{29}$ The Sports and Recreation Institute from Bogota which manages the

301 Ciclovia and Recreovia programs aims to work with residents to increase participation of all

302 residents from the City. Improving geographic access to Ciclovia and Recreovia programs has

303 shown to be a promising strategy to promote park use and PA. ${ }^{28,37}$ Expansion of these programs

304 in low-SES areas can target vulnerable groups, particularly those who are less likely to meet PA

305 recommendations during their leisure time. The provision of a cost-free community program

306 may be an effective approach and a good investment for the health of low-SES populations.

307 According to the government plan from the City Major, the goal is to make of Bogota the world

308 capital of the bicycle. ${ }^{54}$ He pledged to increase and improve bicycle infrastructure in Bogota, but

309 unfortunately progress in the last three and half years has been slow. ${ }^{55}$ There is also not a specific

310 plan to increase equity for all regardless of socio economic strata, which is a serious problem as

311 reported in this study and elsewhere.

312

313 Planning and implementation of complex initiatives like Ciclovia and Recreovia must involve

314 input from a combination of local communities, policy makers, practitioners, advocacy groups, 315 researchers, local businesses, and stakeholders from the transportation, planning and public

316 health sectors. It is important to identify goals (e.g., increased PA, recreation, awareness of

317 bicycling infrastructure, increased spending) ${ }^{24}$ and measure success to ensure long-term

318 sustainability of these initiatives. In addition, in unequal societies such as Colombia in which 
319 there are remarkable democratic deficits, the participation in advocacy processes is determined

320 by the socioeconomic hierarchy. ${ }^{56}$ This should be examined in futures studies in the area of

321 urban health.

322

\section{Conclusion}

324 Worldwide, interest in Ciclovia initiatives continues to grow and this study serves as a source of 325 PA and community connectivity. Findings have high relevance for Bogotá and for other cities 326 from developing countries, where community initiatives to promote PA at the population level 327 can result in substantial public health benefits. However, an effort must be made to eliminate 328 issues of disparity by having programs like the Ciclovia and Recreovia reach areas of low SES.

\section{Funding \& Acknowledgements}

332 This project was supported in part by funds from the Institute for Public Health at Washington 333 University in St.Louis. We are grateful to Dr. Parra's research assistants Andrea Gaona Romero 334 and Alexandria Van Zandt, who provided important feedback in the manuscript and acted as 335 editors for the English language. 


\section{References}

351 1. Paez DC, Reis RS, Parra DC, et al. Bridging the gap between research and practice: an assessment of external validity of community-based physical activity programs in Bogota, Colombia, and Recife, Brazil. Translational behavioral medicine. 2015;5(1):1-11.

2. Reis RS, Yan Y, Parra DC, Brownson RC. Assessing participation in community-based physical activity programs in Brazil. Medicine and science in sports and exercise. 2014;46(1):92-98.

3. Herens M, Wagemakers A, Vaandrager L, Van Ophem J, Koelen M. Evaluation design for community-based physical activity programs for socially disadvantaged groups: communities on the move. JMIR Res Protoc. 2013;2(1):e20.

4. Wilcox S, Dowda M, Griffin SF, et al. Results of the first year of active for life: translation of 2 evidence-based physical activity programs for older adults into community settings. Am J Public Health. 2006;96(7):1201-1209.

5. Parra D, Gomez L, Pratt M, Sarmiento OL, Mosquera J, Triche E. Policy and built environment changes in Bogota and their importance in health promotion. Indoor Built Environ. 2007;16(4):344-348.

6. IDRD. Ciclovía Bogotana. Alcaldia Mayorde Bogota. https://www.idrd.gov.co/cicloviabogotana. Published 2017. Accessed April 4, 2019.

7. Hipp JA, Bird A, van Bakergem M, Yarnall E. Moving targets: Promoting physical activity in public spaces via open streets in the US. Prev Med. 2017;103S:S15-S20.

8. Cohen D, Han B, Derose KP, Williamson S, Paley A, Batteate C. CicLAvia: Evaluation of participation, physical activity and cost of an open streets event in Los Angeles. Prev Med. 2016;90:26-33.

9. Eyler AA, Hipp JA, Lokuta J. Moving the Barricades to Physical Activity: A Qualitative Analysis of Open Streets Initiatives Across the United States. Am J Health Promot. 2015;30(1):e50-58.

10. Kuhlberg JA, Hipp JA, Eyler A, Chang G. Open streets initiatives in the United States: closed to traffic, open to physical activity. J Phys Act Health. 2014;11(8):1468-1474.

11. Hipp JA, Eyler AA, Zieff SG, Samuelson MA. Taking physical activity to the streets: the popularity of Ciclovia and Open Streets initiatives in the United States. Am J Health Promot. 2014;28(3 Suppl):S114-115.

12. Hipp JA, Eyler AA, Kuhlberg JA. Target population involvement in urban ciclovias: a preliminary evaluation of St. Louis open streets. J Urban Health. 2013;90(6):1010-1015.

13. Montero S. Worlding Bogota's Ciclovia From Urban Experiment to International "Best Practice". Lat Am Perspect. 2017;44(2):111-131.

14. Engelberg JK, Carlson JA, Black ML, Ryan S, Sallis JF. Ciclovia participation and impacts in San Diego, CA: The first CicloSDias. Preventive Medicine. 2014;69:S66-S73.

15. Perry CK, Ko LK, Hernandez L, Ortiz R, Linde S. Ciclovia in a Rural Latino Community: Results and Lessons Learned. J Public Health Man. 2017;23(4):360-363.

16. Zieff SG, Hipp JA, Eyler AA, Kim MS. Ciclovia Initiatives: Engaging Communities, Partners, and Policy Makers Along the Route to Success. J Public Health Man. 2013;19:S74-S82. 
17. Gomez LF, Sarmiento R, Ordonez MF, et al. Urban environment interventions linked to the promotion of physical activity: a mixed methods study applied to the urban context of Latin America. Social science \& medicine. 2015;131:18-30.

18. UN-Habitat. State of Latin American and Caribbean Cities Report 2012. United Nations ;2012.

19. Observatorio Ambiental de Bogota. oab2.ambientebogota.gov.co/apc-aafiles/.../indicadores_bogot.pdf. Published 2017. Accessed.

20. Zieff SG CA, Musselman M. . Creating neighborhood recreational space for youth and children in the urban environment: Play(ing in the) Streets in San Francisco. . Children and Youth Services Review. 2016;70:95-101.

21. Diaz Del Castillo A, Sarmiento OL, Reis RS, Brownson RC. Translating evidence to policy: urban interventions and physical activity promotion in Bogota, Colombia and Curitiba, Brazil. Translational behavioral medicine. 2011;1(2):350-360.

22. Sarmiento OL, Rios AP, Paez DC, Quijano K, Fermino RC. The Recreovia of Bogota, a Community-Based Physical Activity Program to Promote Physical Activity among Women: Baseline Results of the Natural Experiment Al Ritmo de las Comunidades. Int J Environ Res Public Health. 2017;14(6).

23. Abolghasem S, Gomez-Sarmiento J, Medaglia AL, et al. A DEA-centric decision support system for evaluating Ciclovia-Recreativa programs in the Americas. Socio-Econ Plan Sci. 2018;61:90-101.

24. Encuesta Nacional de la Situación Nutritional, ENSIN 2015. Bogotá: Gobierno de Colombia, Universidad Nacional de Colombia, Instituto Nacional de Salud, Instituto de Bienestar Familiar. ;2019.

25. Diaz Del Castillo A, Gonzalez SA, Rios AP, et al. Start small, dream big: Experiences of physical activity in public spaces in Colombia. Preventive medicine. 2017;103S:S41-S50.

26. Sarmiento OL, Díaz Del Castillo A, Triana CA, Acevedo MJ, Gonzalez SA, Pratt M. Reclaiming the streets for people: Insights from Ciclovías Recreativas in Latin America. Preventive medicine reports. 2017;103S:S34-S40.

27. Lim SS, Vos T, Flaxman AD, et al. A comparative risk assessment of burden of disease and injury attributable to 67 risk factors and risk factor clusters in 21 regions, 19902010: a systematic analysis for the Global Burden of Disease Study 2010. Lancet. 2012;380(9859):2224-2260.

28. Teunissen T, Sarmiento OL, Zuidgeest M, Brussel M. Mapping Equality in Access: The Case of Bogotá's Sustainable Transportation Initiatives. International Journal of Sustainable Transportation. 2015;9(7):457-467.

29. Gonzalez S, Lozano O, Ramirez A, Grijalba C. [Physical activity levels among Colombian adults: inequalities by gender and socioeconomic status]. Biomedica. 2014;34(3):447459.

30. Torres A, Sarmiento OL, Stauber C, Zarama R. The Ciclovia and Cicloruta programs: promising interventions to promote physical activity and social capital in Bogota, Colombia. Am J Public Health. 2013;103(2):e23-30.

31. Meisel JD, Sarmiento OL, Montes F, et al. Network analysis of Bogota's Ciclovia Recreativa, a self-organized multisectorial community program to promote physical activity in a middle-income country. Am J Health Promot. 2014;28(5):e127-136. 
32. Sarmiento O, Torres A, Jacoby E, Pratt M, Schmid TL, Stierling G. The Ciclovia-Recreativa: A Mass-Recreational Program With Public Health Potential. J Phys Act Health. 2010;7:S163-S180.

33. Gomez LF, Mosquera J, Gomez OL, et al. Social conditions and urban environment associated with participation in the Ciclovia program among adults from Cali, Colombia. Cadernos de saude publica. 2015;31 Suppl 1:257-266.

34. Mosquera J, Parra D, Gomez L, Sarmiento O, Schmid T, E. J. An Inside Look at Active Transportation in Bogotá: A Qualitative Study. J Phys Act Health. 2012;9(6).

35. Montes F, Sarmiento OL, Zarama R, et al. Do health benefits outweigh the costs of mass recreational programs? An economic analysis of four Ciclovia programs. J Urban Health. 2012;89(1):153-170.

36. Parra DC, Gomez LF, Pinzon JD, Brownson RC, C. M. Equity in cycle lane networks: examination of the distribution of the cycle lane network by socioeconomic index in Bogotá, Colombi. Cities \& Health. 2018;2:60-68.

37. CATASTRO. Mapa de Referencia. https://www.ideca.gov.co/es/servicios/mapa-dereferencia. Published 2018. Accessed.

38. IDRD. Historia ciclovía Bogotana. IDRD. https://www.idrd.gov.co/historia-cicloviabogotana. Published 2017. Accessed 2/15/2019, 2019.

39. Bogota Cd. PROYECTO DE ACUERDO 478 DE 2017 Por medio del cual se adoptan lineamientos para institucionalizar el desarrollo, la gestión de la Bicicleta en el Distrito Capital y se dictan otras disposiciones In: Bogota AMd, ed. Bogota, Colombia: Alcaldia de Bogota; 2015.

40. CONPES. LA ESTRATIFICACIÓN SOCIOECONÓMICA AVANCE Y RETOS. In: Planeacion Dnd, ed. Bogota1997.

41. DANE. Proyecciones de Poblacion. Bogota: DANE;2005.

42. Uribe $C$, Vásquez $S$, Pardo C. Subsidiar y segregar: la política de estratificación y sus efectos sobre la movilidad social en Bogotá. Pap.polit. 2006; 11(1): 69-94.

43. Shahid R, Bertazzon S, Knudtson M L, Ghali WA. Comparison of distance measures in spatial analytical modeling for health service planning. BMC Health Serv Res. 2009;9:200.

44. Rodrigues DE, Cesar CC, Kawachi I, Xavier CC, Caiaffa WT, Proietti FA. The Influence of Neighborhood Social Capital on Leisure-Time Physical Activity: a Population-Based Study in Brazil. Journal of Urban Health-Bulletin of the New York Academy of Medicine. 2018;95(5):727-738.

45. Dias-da-Costa JS, Hallal PC, Wells JC, et al. Epidemiology of leisure-time physical activity: a population-based study in southern Brazil. Cad Saude Publica. 2005;21(1):275-282.

46. IDRD. Recreovia. https://www.idrd.gov.co/recreovia. Published 2017. Accessed 2/15/2019, 2019.

47. IDRD. Ciclovia. IDRD. https://www.idrd.gov.co/boletin-ciclovia-idrd. Published 2017. Accessed 2/15/2019, 2019.

48. Bernatchez AC, Gauvin L, Fuller D, Dube AS, Drouin L. Knowing about a public bicycle share program in Montreal, Canada: Are diffusion of innovation and proximity enough for equitable awareness? J Transp Health. 2015;2(3):360-368. 
478 49. Beiler MO, McGoff R, McLaughlin S. Trail Network Accessibility: Analyzing Collector

479 Pathways to Support Pedestrian and Cycling Mobility. J Urban Plan Dev. 2017;143(1).

480 50. Barreto L. Peñalosa declaró a Bogotá 'Capital Mundial de la Bicicleta'. Bogota. August 6, $481 \quad 2018,2018$.

482 51. Rojas F. El POT de Peñalosa y la movilidad de Bogotá Razon Publica2019.

483 52. Vasquez E, E. , Perez-Brumer A, Parker R, G. . Social inequities and contemporary struggles for collective health in Latin America. . Global Public Health 2019;14(6-7):777485790. 